\title{
Distribution and Ecology of Euglenoids in Selected Lakes of Tumakuru District, Karnataka
}

\author{
V. N. Murulidhara ${ }^{1}$ and V. N. Yogananda Murthy ${ }^{2 *}$ \\ ${ }^{1}$ Department of Botany, Government First Grade College of Arts, Science and Commerce, Sira, \\ Karnataka, India. \\ ${ }^{2}$ Department of Biotechnology, Azyme Biosciences Pvt. Ltd. Bengaluru, Karnataka, India.
}

\begin{abstract}
Authors' contributions
This work was carried out in collaboration between both authors. Author VNM designed the study, managed the analyses of the study, wrote the protocol and penned the first draft of the manuscript. Author VNYM managed the literature searches and performed the statistical analysis. Both authors read and approved the final manuscript.

Article Information

DOI: $10.9734 / A R R B / 2018 /$ v30i430019

Editor(s):

(1) Dr. Manikant Tripathi, Department of Microbiology, Dr. Ram Manohar Lohia Avadh University, India.

(2) Prof. George Perry, Dean and Professor of Biology, University of Texas at San Antonio, USA.

Reviewers:

(1) Hamaidi-Chergui Fella, University of Blida, Algeria.

(2) Lokuhewage Asha Udayamali Meegolle, Japan.

Complete Peer review History: http://www.sdiarticle3.com/review-history/47293
\end{abstract}

Original Research Article

Received 26 October 2018

Accepted 23 February 2019

Published 07 March 2019

ABSTRACT

Aim: This study deals with the distribution and ecology of euglenoids in relation to physicochemical characteristics of water in four lakes of Tumakuru district.

Place and Duration of Study: Guluru, Bugudanahalli, Colony and Teeta are the four lakes of Tumakuru district selected for the present study during 2015-17.

Methodology: Euglenoids function as indicators of aquatic superiority. Composite samples were taken at two feats depth from surface level on monthly basis for the enumeration of euglenoids. Results: A total of ten species under three genera were identified. Guluru lake harboured $46.66 \%$ followed by Colony and Teeta lakes $20 \%$ each and Bugudanahalli lake with $13.33 \%$. Seasonally all the lakes recorded maximum density of euglenoids during summer except in Colony lake, where they reached their peak during rainy season. Euglenoids showed significant positive correlation with water temperature $(r=0.664: P<0.05)$, Sulphate $(r=0.757: P<0.05)$ and Silica $(r=0.775: P<$ $0.05)$ at $5 \%$ level.

*Corresponding author: E-mail: dryoganand16@gmail.com,drvnyoganand16@gmail.com; 
Conclusion: Euglenoids established negative correlation with dissolved oxygen and ammoniacal nitrogen. As the euglenoids serve as pollution indicator organisms, moderate density of euglenoids in the lakes investigated indicates that, lakes are tending towards biologically eutrophic condition.

Keywords: Correlation; euglenoids, lake; physico-chemical characters.

\section{INTRODUCTION}

Euglenophytes comprises distinct group of free living protists which are phototrophic species, colourless phagotrophic and osmotrophic species, bacteriophagic in nature [1,2]. Euglenoids are group of motile fresh water flagellates often produce water bloom in ponds and lakes, which gives red colouration to the water due to the presence of characteristic euglenoid pigment called astaxanthin. The class euglenophyceae is an important group in terms of its richness and abundance in shallow aquatic ecosystems with higher concentrations of organic materials [3,4]. Euglenoids often serve as indicators of organic pollution [5]. They also serve as connecting organisms between flora and fauna [6]. Occurrence of euglenophyceaean members in fresh water bodies pointed towards the possibility of eutrophication and they act as pollution indicator groups [7]. Water is the utmost imperative abiotic aspect backing life. The physico-chemical possessions of water monitor the lifespan of aquatic animals existing in water. Any alteration in the water eminence has straight impact on biotic populations where diverse species of flora and fauna display unlimited variations in their responses to the reformed environment $[8,9]$. Euglenophytes are one of the important groups of plankton occupy shallow aquatic ecosystem in large numbers due to high concentrations of organic materials to the environment. The species richness and abundance make this group unique to nutrient rich water body. 41 species of euglenoids under 6 genera were reported from brackish water ecosystems of Indian Sundarbans biosphere reserve [10]. The relationship between certain physico-chemical parameters and euglenaphyceae indicates that, the quality of water plays an important role in the distribution of euglenophyceae [11]. Euglenaria clepsydroides is recorded first time from Thiruvananthapuram Museum lake from India, Which was earlier reported from Poland [12]. Higher species richness of euglenoids is reported during summer months from a eutrophic reservoir in Central Mexico [13]. Preservation of water superiority for the development of aquatic biota is very significant. There has been no publication yet on the ecology, distribution pattern, seasonal dynamics, relative abundance of euglenoids and their relationship with physico-chemical characteristics of the existing water bodies in the present study area. Hence, an effort has been made with a principal objective of floristic survey of the class euglenophyceae, its distribution pattern, seasonal dynamics, relative abundance and their relationship with different physicochemical parameters in four lakes of Tumakuru district in Karnataka state.

\section{MATERIALS AND METHODS}

\subsection{Study Area}

Guluru, Bugudanahalli, Colony and Teeta are the four lakes situated within the radious of 30 kilometers from Tumakuru city were selected for the study and shown in Fig. 1.

\subsection{Sampling and Sample Analysis}

Two liters of surface water samples were collected from each of these lakes at an interval of 30 days for two years for the estimation of physico-chemical characteristics using standard procedures [14]. Water temperature was measured on the spot with the help of thermometer and expressed in ${ }^{\circ} \mathrm{C}$. Water samples were fixed at each sampling station for the estimation of dissolved oxygen using Winkler's iodometric method. Physico-chemical parameters such as $\mathrm{pH}$, dissolved oxygen, free carbon dioxide, nitrate nitrogen, phosphate, sulphate, ammoniacal nitrogen and silica were estimated using standard procedures and expressed in terms of $\mathrm{mg} / \mathrm{l}$ except $\mathrm{pH}$. Water samples were also collected simultaneously from all the four lakes at monthly intervals for a period of two years for the enumeration of euglenophyceae. One liter of water sample from each lake was fixed separately with $20 \mathrm{ml}$ of $1 \%$ lugol solution for 24 hours. $100 \mathrm{ml}$ of sediment sample from each lake is centrifuged at 1500 rpm for 45 minutes and $10 \mathrm{ml}$ of the sediment from each sample is preserved for the enumeration of euglenoids. For diversity studies camera lucida technique was adopted for writing diagrams and euglenoids were identified up to the species level using monographs, earlier 
research works and manuals [15-17]. The density of euglenoid population was calculated by using standard procedures [18]. Biannual averages of physico-chemical parameters were calculated. Seasonal variations and relative abundance of euglenoids were also enumerated and represented in figures.

\subsection{Statistical Analysis}

Carl pearson's correlation co-efficient was employed to establish the relationship between euglenoid population and physico-chemical parameters.

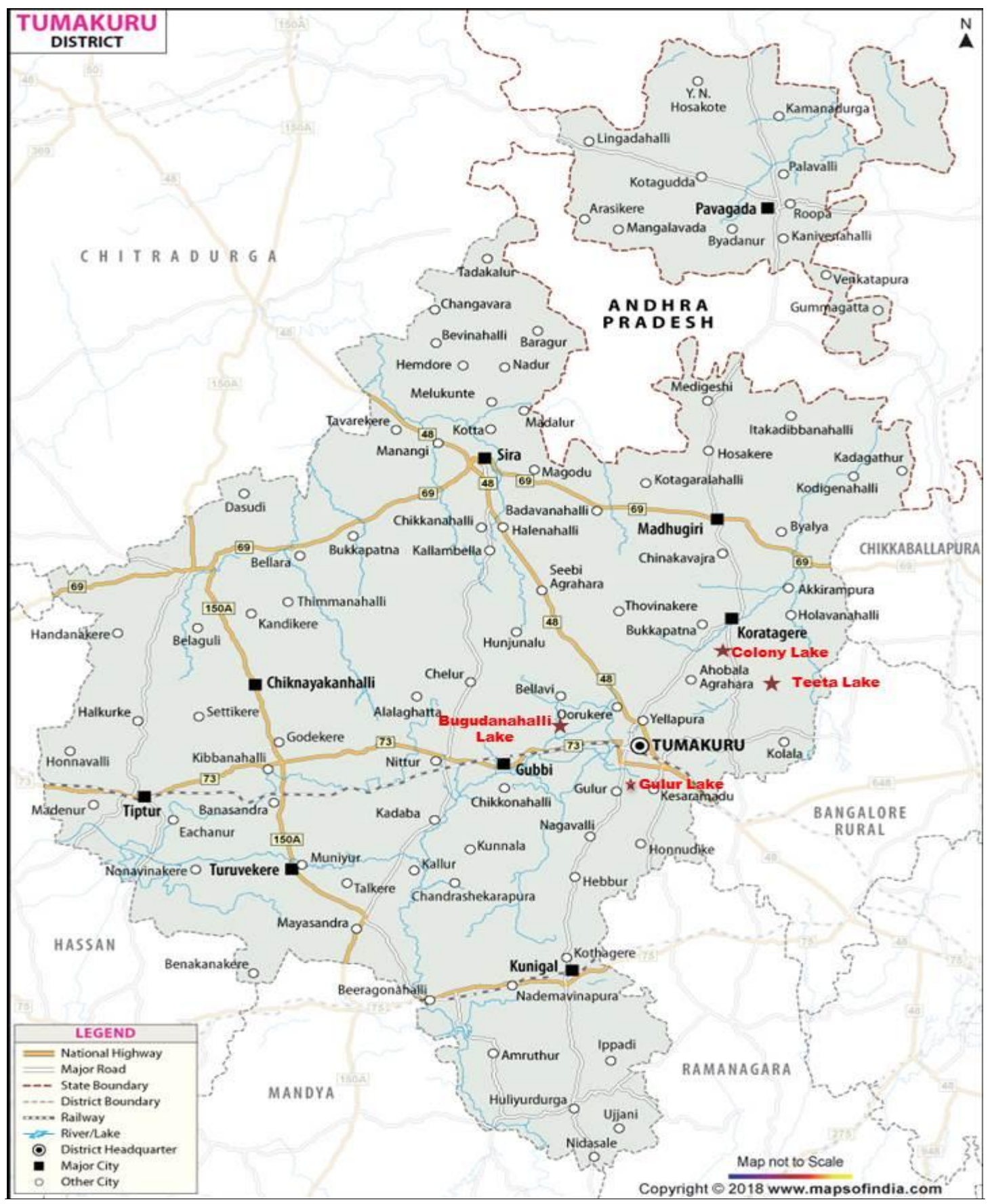

Fig. 1. Map showing the location of the selected sampling lakes in Tumakuru district 


\section{RESULTS AND DISCUSSION}

Euglenophyceae are generally abundant in waters rich in organic matters [19]. A total of 10 species of euglenophyceae under 3 genera were recorded during the present study. Camera Lucida diagrams of the euglenoids recorded during the study are represented in Fig. 2.

Euglena is represented by 4 species. Phacus is considered to be dominant genera of polluted waters [20]. The genus Phacus in the present investigation is represented by 5 species which indicates the presence of higher pollution load. The genus Tracheolomonas is represented by single species (Table 1).

Seasonally three of the four lakes investigated recorded maximum density of euglenoids during summer, except in Colony lake where they showed their peak during rainy season. Seasonal variations and relative abundance of euglenoids are represented in Fig. 3 and Fig. 4 respectively. Biannual average values of physico-chemical parameters related to this group are described (Table 2).

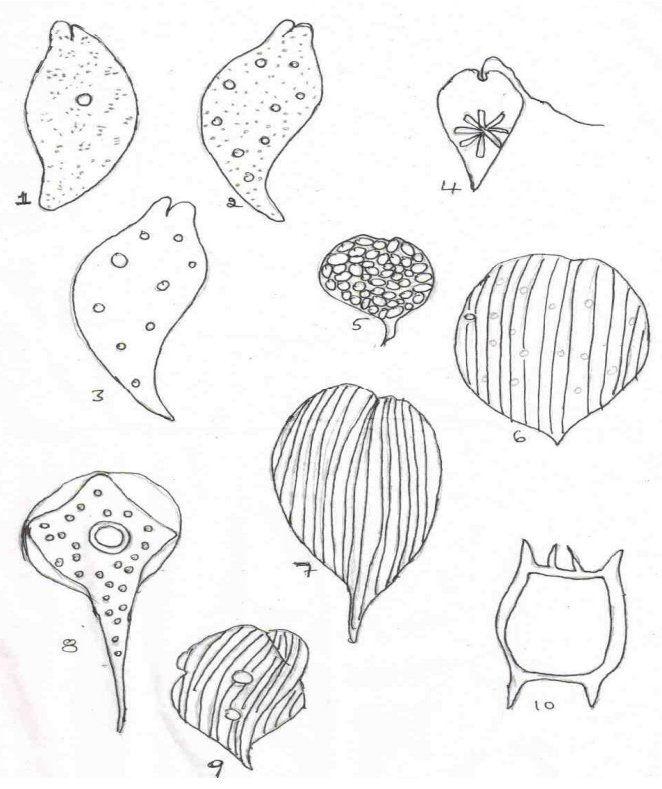

Fig. 2. Camera lucida diagrams of euglenoids

Table 1. Occurrence of euglenoids in selected lakes of Tumakuru District (2015-2017)

\begin{tabular}{llllll}
\hline SI.No. & Name of the organisms & \multicolumn{4}{c}{ Lakes } \\
\cline { 3 - 6 } & Euglena minuta & + & - & Colony & Teeta \\
\hline 1 & Euglena polymorpha & + & - & - & + \\
2 & Euglena proxima & + & - & - & - \\
3 & Euglena nirids & - & + & - & + \\
4 & Phacus accuminatus & + & - & - & - \\
5 & Phacus amkylonoton & + & - & + & - \\
6 & Phacus caudatus & - & + & + & - \\
7 & Phacus hispidulus & - & - & - & - \\
8 & Phacus undulates & + & - & + & - \\
9 & Tracheolomonas armata & + & - & - & - \\
10 & & $+=$ &
\end{tabular}

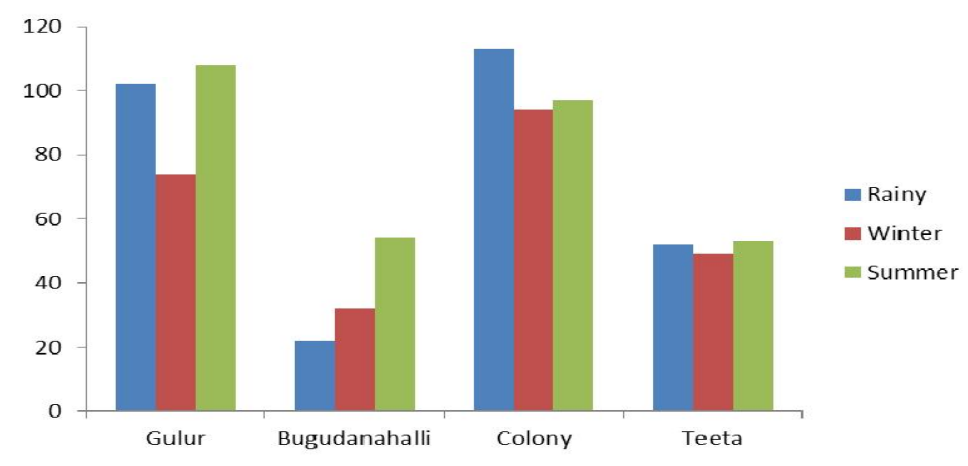

Fig. 3. Seasonal variations of euglenoids in selected lakes of Tumakuru District 


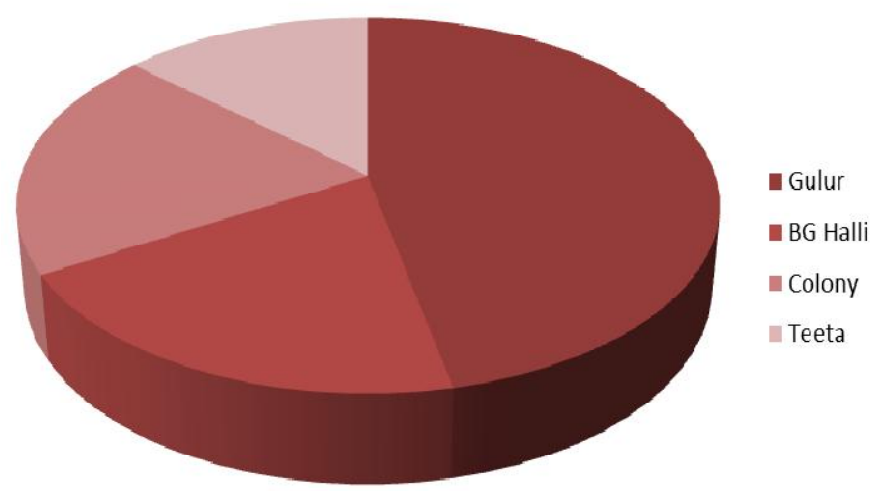

Fig. 4. Relative abundance of euglenoids in selected lakes of Tumakuru District

Table 2. Biannual averages of certain related physico-chemical factors (2015-17)

\begin{tabular}{llllll}
\hline SI.No. & Factors & Guluru & Bugudanahalli & Colony & Teeta \\
\hline 1 & Water temperature & 26.45 & 27.16 & 27.62 & 26.75 \\
2 & Dissolved oxygen & 7.93 & 7.60 & 7.47 & 8.08 \\
3 & Free $\mathrm{CO}_{2}$ & 10.98 & 8.0 & 3.05 & 1.66 \\
4 & Nitrate nitrogen & 6.48 & 0.4 & 0.39 & 0.69 \\
5 & Phosphate & 0.81 & 0.23 & 0.18 & 0.28 \\
6 & Sulphate & 73.86 & 39.91 & 30.22 & 30.53 \\
7 & Ammonical nitrogen & 3.55 & 2.34 & 2.0 & 1.75 \\
8 & Silica & 35.31 & 109.8 & 139.6 & 40.48 \\
\hline
\end{tabular}

Table 3. Carl Pearson's correlation matrix euglenoids V/S physico-chemical factors

\begin{tabular}{lll}
\hline SI.No. & Physico-chemical factors & Euglenoids $\mathbf{r}$ - value \\
\hline 1 & Water temperature & $0.664^{\star} 0.000$ \\
2 & Dissolved oxygen & -0.5970 .002 \\
3 & Free $\mathrm{CO}_{2}$ & -0.3760 .070 \\
4 & Nitrate nitrogen & $0.425^{*} 0.038$ \\
5 & Phosphate & 0.1390 .516 \\
6 & Sulphate & $0.757^{*} 0.000$ \\
7 & Ammonical nitrogen & -0.7250 .000 \\
8 & Silica & $0.775^{\star} 0.000$ \\
\hline
\end{tabular}

In order to understand positive and negative impact of physico-chemical parameters on euglenophycean population, the values of physico-chemical parameters and occurrence of euglenoid population were subjected to Carl pearson's correlation coefficient and the results obtained are portrayed in Table 3.

The ecological distribution of euglenoids was studied by so many workers [21,22]. The role of temperature, organic matter and albuminoid ammonia on the growth and development of euglenophyceae was discussed by many scientists $[23,24]$. Many scientists have attributed the distribution of euglenoids to the concentration of free carbon dioxide, dissolved oxygen and phosphate where, higher concentration of free carbon dioxide coupled with low amount of dissolved oxygen influences the multiplication of euglenoids [25-28]. In the present investigation concentration of carbon dioxide and dissolved oxygen were found to be low in all the lakes with less margin between them. Hence, it is concluded that, these two parameters have not much influence on the distribution and abundance of euglenoids. This is also evidenced by correlation matrix where dissolved oxygen showed negative bearing on the distribution of euglenoids and free carbon dioxide remained as an independent variable (Table 3).

It was concluded that temperature of the range $25-28^{\circ} \mathrm{C}$ enhanced the growth of euglenoids [27]. In the present investigation, temperature range 
between $26.45^{\circ} \mathrm{C}$ to $27.62^{\circ} \mathrm{C}$ influenced the average growth of euglenoids. However, water temperature showed positive correlation with growth and dynamics of euglenoids $(r=0.664)$ at $5 \%$ level (Table 3 ). Similar observations have been made by other workers [29]. The multiplication of euglenophyceae is less when the water temperature is below $25^{\circ} \mathrm{C}[24,30]$. Hence, it is apparent that the water temperature between $26-28^{\circ} \mathrm{C}$ is congenial for the growth of euglenoids (Tables 1, 2 \& Fig. 1). The present findings are in conformity with the above findings. It was suggested that higher concentrations of nitrate nitrogen promote the growth of euglenoids [30]. Similar feature was observed in the present study also where nitrate nitrogen remained positively correlated to the abundance and dynamics of euglenoids at significant level (Table. 3). Increase in the concentration of phosphate favours the abundant growth of euglenophyceae [5]. This is not in accordance with the results of the present investigation where, phosphate remained as an independent variable and did not show any influence on the diversity and distribution of euglenoids (Table. 3). It was observed from polluted lentic water bodies of Jammu and reported that, the rich growth of pollution tolerant species is due to the increase in nutrients by the decomposing macrophytic vegetation in lake during summer and inlet of agricultural runoff during monsoon which carries organically rich water in to the lake [31,32]. Similar observations were reported by many other workers [33-37]. In the present investigation, sulphate concentration varied between $30.22 \mathrm{mg} / \mathrm{l}$ in Colony lake and 73.86 $\mathrm{mg} / \mathrm{l}$ in Guluru lake (Table. 2) and showed significant positive correlation $(r=0.757)$ at $5 \%$ level with the distribution of euglenoids. However, ammonical nitrogen established a negative bearing on the dynamics of euglenoids (Table. 3). Silica also showed positive bearing on the ecology and distribution of euglenoids $(r=0.775)$ at significant level (Table 3$)$.

\section{CONCLUSION}

From the results, it is concluded that, higher concentration of euglenoids during summer season is due to surface runoff from agricultural fields. Study also helped in understanding the distribution of euglenoids in Tumakuru district lakes and the physico-chemical factors having positive bearing on their growth. Carl pearson's correlation coefficient served as an important tool in understanding the impact of different physicochemical parameters on the distribution of euglenoids. As the euglenoids serve as pollution indicator organisms, moderate density of euglenoids in the lakes investigated indicates that, lakes are tending towards biologically eutrophic condition. The data obtained is also helpful in deriving the conservational strategies.

\section{COMPETING INTERESTS}

Authors have declared that no competing interests exist.

\section{REFERENCES}

1. Brosnan S, Shin W, Kjer LM, Trimer RE. Phylogeny of the photosynthetic euglenophytes inferred from the nuclear SSU and partial LSU rDNA. Int J Syst Evol Microbiol. 2003;53:1175-1186.

DOI: 10.1099/ijs.0.02518-0

2. Marin B, Palm A, Klingber M, Melkonian M. Phylogeny and taxonomic revision of plastid-containing euglenophytes based on SSU rDNA sequence comparisons and synapomorphic signatures in the SSU rRNA secondary structure. Protist. 2003; 154:99-145.

3. Tell G, Conforti V. Euglenophyta pigmentadas de la Argentina, (Bibliotheca Phycologica 75) Berlin. J Cramer. 1986; 301.

4. Shashi J. Singh, Anil K. Dwivedi. Numerical interdependence in $\mathrm{pH}$, acidity and alkalinity of polluted river water. J Environ Biol. 2009;30(5):773-775.

5. Shankar P. Hosmani. Multivariate analysis for distribution of euglenophyceae in Karanji lake of Mysore. Phykos. 2012; 42(2):74-79.

6. Priyanka Sharma, Nilima Bhardwaj. Algal biodiversity in some water bodies of Kota, Rajasthan, India. Int Res J Biological Sci. 2017;6(9):7-14.

7. Mohamed Naseer KM, Sureshkumar S. Interaction between microalgal species richness and environmental variables in Peringalkuthu reservoir, Western Ghats, Kerala. J Environ Biol. 2013;34:10011005.

8. Abalaka SE. Evaluation of the haematology and biochemistry of Clarias gariepinus as biomarkers of environmental pollution in Tiga Dam Nigeria. Braz Arch Biol Technol. 2013;56(3):371-376.

9. Watson SB, Lawrence J. Overview Drinking water quality and sustainability. 
Water Qual. Res J Canada. 2003;38(1):313.

10. Gour Gopal Satpati, Ruma Pal. Taxonomic diversity and SEM study of euglenoids from brackish water ecosystem of Indian Sundarbans Biosphere reserve. Phykos. 2017;47(1):105-122.

11. Nagaraja $P$, Narayana J. Euglenoids distribution in relation to water quality of Konandur pond, Thirtahalli taluk, Karnataka. Proc of $10^{\text {th }}$ Biennial Lake Conference; 2016.

12. Anila P. Ajayan, Ajit Kumar KG. New geographic distribution of Euglenaria clepsydroides (Euglenophyceae) from India. Indian J Trop Biodiv. 2016;24(1): 100-102.

13. Gloria GS, Maria G, Alfonso LV, Maria BMG, Rafael EQZ, Visitacion C. Trachelomonas (Euglenophyta) from a eutrophic reservoir in Central Mexico. J Environ Biol. 2011;32:463-471.

14. American Public Health Association (APHA). Standard methods for the examination of water and waste water $\left(20^{\text {th }}\right.$ edn.) Washington D.C; 2008.

15. Adoni AD, Gunwant Joshi, Kartik Ghosh, Chourasia SK, Vaishya AK, Manoj Yadav, Verma HG. Work book on limnology. Prathiba publishers, Sagar, India; 1985.

16. Smith GM. The fresh-water algae of United States. McGraw-Hill Book Company, Inc. 1950;3:594.

17. Prescott GW. Algae of the western great lakes area. Otto Koeltz Science publishers, Koenigstein, W Germany. Bishen Singh Mahendra Pal Singh, Dehra Dun. 1962;1965.

18. Rao CB. On the distribution of algae in a group of six small ponds. Algal periodicity. J Ecol. 1955;43:291-308.

19. Kalff J. Limnology prentice hall Uppers addle river. New Jersey; 2000.

20. Alam A, Khan AA. Dynamics of plankton communities in four fresh water lentic ecosystems in relation to varying dominant biota. Poll Res. 1996;15(3):289-291.

21. Munawar M. Limnological studies on fresh water ponds of Hyderabad - India. II. The biocenose - Distribution of unicellular and colonial phytoplankton in polluted and unpolluted environments. Hydrobiol. 1970b;36(1):105-128.

22. Singh U, Swarup DK. Limnological studies of Suraha lake [Ballia] II. The periodicity of phytoplankton. J Indian Bot Soc. 1979;58: 319-329.
23. Sunder Singh. Analysis of plankton diversity and density with physicochemical parameters of open pond in town Deeg (Bhratpur) Rajasthan, India. Int Res J Biological Sci. 2015;4(11):61-69.

24. Murulidhar VN, Yogananda Murthy VN. Ecology, distribution and diversity of phytoplankton in Teetha wetland, Tumakuru district, Karnataka, India. Int J Environ Pollun Res. 2015;3(3):1-12.

25. Seenayya G. Ecological studies on the plankton of certain fresh water ponds of Hyderabad, India. II. Hydrobiol. 1971;41: 529-540.

26. Munawar M. Limnological studies on fresh water ponds of Hyderabad, India IV. The biocenose - Periodicity and species composition of unicellular and colonial phytoplankton in polluted and unpolluted environments. Hydrobiol. 1974;45(1):1-32. DOI: 10.1007/BF00006443

27. Hegde GR, Bharati SG. Comparative phytoplankton ecology of fresh water ponds and lakes of Dharwad, Karnataka, India. Proc. Nat. Symp. Pure and Applied limnology (Eds. A.D.Adoni). Bull Bot Soc Sagar. 1985;32:24-29.

28. Puttaiah ET, Somashekar RK. Distribution of euglenoids in lakes of Mysore city. Phykos. 1987;26:39-46.

29. Altaf H. Ganai, Saltanat Praveen, Asif A. Khan, Maryam H. Phytoplankton diversity at Watlab Ghat in Wular lake, Kashmir. J Ecol Nat Environ. 2010;2(8):140-146.

30. Munawar M. Ecological studies of euglena in certain polluted and unpolluted environments. Hydrobiol. 1972;39(3):307-320.

31. Palmer GW. A composite rating of algae tolerating organic pollution. J Phycol. 1969; 5:78-82

32. Kant $S$. Algae as indicator of organic pollution. Advances in applied phycology (edn Shukla and Pandey). 1985;77-86.

33. Buetow DE. The biology of euglena.V.1. General biology \& ultrastructure. Academic press, New York; 1968.

34. Palmer CM. Algae and water pollution: An illustrated manual on the identification, significance and control of algae in water supplies and in polluted water. University of Michigan Library, Castle House Publication. London; 1977.

35. Round F. Biologia das algas. $2^{\text {nd }}$ ed., Ed Guanabara Dios, Rio de Janeiro; 1983.

36. Rosowski JR. Photosynthetic euglenoids in fresh water algae of North America: ecology and classification (JDWehr,R G 
Sheath, edn) Academic Press, New York. 2003;383-422.

37. Arindham Ganguly, Asish Mandal, Mohammad Ali Khan, Tapas Kumar Dutta, Subrata Raha, Pradeep Kumar Das
Moapatra. Study of physicochemical parameters, planktonic diversity and bacterial load of Clarias batrachus cultivation pond at Bankura, WB, India. Int Res J Biological Sci. 2017;6(12):23-34.

(c) 2018 Murulidhara and Yogananda Murthy; This is an Open Access article distributed under the terms of the Creative Commons Attribution License (http://creativecommons.org/licenses/by/4.0), which permits unrestricted use, distribution, and reproduction in any medium, provided the original work is properly cited.

Peer-review history:

The peer review history for this paper can be accessed here: http://www.sdiarticle3.com/review-history/47293 